\title{
Suppressed Sexuality in Gendered Institutions: A Re- examination of Amitav Ghosh's Ibis Trilogy
}

\author{
Ranita Bain
}

\begin{abstract}
Assistant Professor, Department of English, Mugberia Gangadhar Mahavidlaya, Vidyasagar University, India
\end{abstract} ranitabain84@gmail.com

Received: 03 Nov 2021; Received in revised form: 07 Dec 2021; Accepted: 15 Dec 2021; Available online: 21 Dec 2021 C2021 The Author(s). Published by Infogain Publication. This is an open access article under the CC BY license (https://creativecommons.org/licenses/by/4.0/).

\begin{abstract}
Socializing factors like, schools, parents, peer groups, and legal forces etc. all of them combine together to alienate women from fulfilling their own sexual desires and transform their sexual appetites into a subdued residue. The double standard of sexual morality forbade certain sexual activities for women while permitting the same actions for men. Women themselves know very well that they are not permitted by society to express their sexual feelings or even to enjoy sex in many contexts. Amitav Ghosh explores this double standard of sexual morality in his novels.He stresses on the need to deconstruct the cultural construct of sexual morality, which prohibited certain sexual behaviours for women while approving the same behaviours for men. Through an exploration of mainly Ghosh's The River of Smoke, Sea of Poppies and Flood of Fire I have shown that the political purposes of men have often been rested on restraining women from enjoying satisfying sexual pleasure. Sexuality is not at all as restricted or as palpable as most of us believe. I have also argued in this paper that the restriction on human sexual activity to the lone task of producing babies is not at all a natural requirement, but it is the outcome of a very precise cultural construction.
\end{abstract}

Keywords-Hedonism, Morality, Religion, Sexuality, Suppression.

Sexuality is a term, which is used to talk about how we perceive our bodies and how we understand our relationships. It is an issue in which social values are often translated into legal norms.Countless women grew up and lived their lives with far less sexual pleasure than they would have enjoyed in the absence of such social and legal norms. It forced women into a state of sexual repression, where they are unable to express their own sexuality. According to psychoanalyst M. J. Sherfey, the sex drive of the human female is naturally and innately stronger than that of the male, and it posed a powerfully destabilizing threat to the possibility of patriarchal social order. So, for civilized society to develop, it was allegedly necessary or at least helpful for female sexuality to be suppressed. Socializing factors like, schools, parents, peer groups, and legal forces etc. all of them combine to alienate women from fulfilling their own sexual desires and transform their sexual appetites into a subdued residue. The double standard of sexual morality forbade certain sexual activities for women while permitting the same actions for men. Women themselves know very well that they are not permitted by society to express their sexual feelings or even to enjoy sex in many contexts. As a result of this, men have also to suffer, at least indirectly, insofar as they have been deprived of the pleasures coming from having partners who enjoy sex too. A very large numbers of people worked together to suppress female sexuality; but that does not mean to imply that they were consciously or deliberately conspiring against women. Rather, we can say, that they may have come to participate in these processes without full consciousness of what they were doing, simply because of situational forces and self-interest they were impelled to act in ways that contributed in bringing female sexuality under restrictive control.

The political aims of men have often been depended on resisting women from having gratifying sexual pleasure. 
According to David M. Buss, the main advantage men derive by suppressing female sexuality is an improvement in certainty about paternity. A man never wants another man to get his wife pregnant. Men definitely want to pass on their genes, and as we know, a woman can have only about one offspring per year, men feel the need to guard their female partners to prevent other men impregnating them. Convincing women to relinquish sexual desire could be a helpful strategy. There are other opinions too. Such as, if a woman lacks desire it will be less likely that she would have sex with others, and thus, her male partner can be relatively more confident that any children she bears will be his own. It will stabilize the property rights and the property will be passed on to legitimate heirs.

Thus, "the ruthless subjugation of female sexuality" (Sherfey 119) became necessary. This analysis was found in other feminist texts too. Reasonably, our patriarchal society decided that "if women are insatiable creatures, their sexuality would, of course, require external constraints, or sexual chaos would reign" (Faunce \& Phillips-Yonas 86). According to some feminists, "In prehistoric human societies, the powerful sex drive of women created havoc-not to mention making the men feel insecure - and therefore societies instituted restrictions on female sexuality to bring it more in line with male sexuality" (Hyde \& De Lamater 360). They also add to this thought that these are "the restrictions on female sexuality that persist to the present day" (360); "the sexual regulation of women .... is one of the foundations upon which the state rests" (140) and is "an essential feature of patriarchal power" (140)

Religion has a big role to play in suppressing female sexuality, insofar as religious traditions have generally advocated sexual restraint. Undoubtedly, many women have felt guilt about enjoying sexual pleasures, and religious faith was always there to provide one such source of guilt. Religion has always been dominated by men, and nearly all major religious figures in world history have been male. Thus, religion can be regarded as a male form of dominance. The Hindu religion from immemorial imprinted in the hearts and minds of the pious Hindu women that women should obey her husband, undergo suffering and should be chaste. According to Manu (Doniger 147-148), the great Indian sage, women should not be allowed to do any work independently either inside the house or outside the house. In the childhood she needs to be under the control of her father and brothers and after marriage she is under the control of her husband.Christian religion, like all other religions in the world, exerted a restraining influence on female sexuality. Christian doctrines and sermons encourage sexual restraint and virtue.According to Tannahill, Christianity was far more hostile to women enjoying sexual pleasure than any other religion of the time when it first took its form. It was intolerant to many sexual practices that were tolerated by other religions of the time, like masturbation and homosexuality. Further, there are other evidence that shows the importance of religion in restraining female sexuality. Women who follow religious teachings strictly feel more guilt than other women about many sexual activities, and they act in ways suggesting sexual repression.

The world of classical Greece and Rome is where the Western civilization mainly derived its moral values from. That is to say, that among other things, that many of the present attitudes (like sexual attitudes) are rooted in a far distant past. Though this basic approach was shared by all ancient cultures, yet the precise definition of sexual orthodoxy or heresy depended, of course, on their specific religious dogmas. But there is one thing that we should consider, that the ancient Mediterranean cultures were, on the whole, rather tolerant in sexual matters. For example, in case of classical Greece sex was seen as an essential life force, and therefore, all sexual desires were accepted as something good. So, various gods and goddesses of beauty, fertility, and sexual passion were worshipped in temples or on special occasions. It was believed by the Greeks that virtually all of their gods led passionate and varied sex lives. Therefore it was considered proper for mortals to follow this divine path. The Greeks were not at all concerned about sexual abstinence; even their language did not even have any special word for "chastity." Actually, they engage very much in the pursuit of sexual pleasures in all its manifestations. They practised hedonism. Ethical hedonism is said to have been started by Aristippus ${ }^{1}$ of Cyrene, a student of Socrates. According to him pleasure is the highest good. Anyway, the hedonism of ancient Greece was not at all an advice for limitless lust and selfindulgence. Rather, it can be said, that it was a passionate enjoyment of life, a cheerful appreciation of the human body and especially of its sexual activities. Pleasure went hand in hand with reason in complete harmony. Their body never had to be punished or starved only for the sake of the soul. As the Greeks did not imagine a very clear concept of a life after death, they were very much free to live every moment on this earth to the fullest.

As we know Greece was a patriarchal society, and the ideal of beauty was male during its golden age. Although it was a norm for men to marry and raise a family, they were not very much romantically involved with their female mates. Men were passionately involved in romantic homosexual relationships before and outside of marriage. Their sentiments were supported in their religion. It is believed, that Gods like Zeus and Apollo and demigods like 
Hercules have fallen in love with beautiful and handsome young men. There is no doubt that for most of the Greeks these heavenly models were a continuous source of inspiration. Though the evidence about female homosexuality in the ancient Greek world is limited, yet two poets, Sappho and Alcman, have been interpreted as writing about female homosexual desire. The myth of the Amazons $^{2}$ has also been interpreted as referring to female homosexual activities. In medieval Europe, the Christian Church took a stricter view of same-sex relations between women. The Old French legal treatise Li livres de jostice et deplet (1260) is the earliest reference to legal punishment for lesbianism. Thus, our ancientGreek and Roman societies did not try to supress lesbian sexual activities or we can say, homosexuality in general, the way medieval Western societies tried to do so.There is no doubt that even in modern times homosexual behaviour has been severely and often brutally suppressed in many societies around the world. As we know, lesbian activity is an important form of female sexuality, and psychoanalysis can serve as an important tool for proper understanding of cultural suppression of female sexuality. According to Freud homosexuality is 'an arrest of sexual development'. His main discussion of female homosexuality was the 1920 paper "The Psychogenesis of a Case of Homosexuality in aWoman," which described his analysis of a young woman who had entered therapy because her parents were concerned that she was a lesbian. Her father hoped that psychoanalysis would cure her lesbianism. Few years later, Simone de Beauvoir explained the discourse of psychoanalysis in The Second Sex (1980 [1949]). She devoted an entire chapter to her distrust of "The Psychoanalytic Point of View" (Beauvoir 1980, 73-85). Beauvoir denounces Freud's idea that there is but one, masculine, libido and no feminine libido with "its own original nature" (Beauvoir 1989). Freud, in her view, takes for granted what he needs to account for, namely the value placed on virility. Beauvoir rejects Freud's ideas for not taking into consideration the social origins of masculine and paternal power and privilege and considers his theory inadequate to account for woman's otherness. If women envy men, she argues, it is because of the social power and privilege they enjoy, and not because of anatomical superiority. According to her "Nearly all girls have lesbian tendencies; these tendencies are barely distinguishable from narcissistic delights: in the other, it is the sweetness of her own skin, the form of her own curves, that each of them covets; and vice versa, implicit in her self-adoration is the cult of femininity in general....Homosexuality can be a way for woman to flee her condition or a way to assume it...Woman is an existent who is asked to make herself object; as subject she has an aggressive sensuality that does not find satisfaction in the masculine body: from this are born the conflicts her eroticism must overcome. The system is considered normal that, delivering her as prey to a male, restores her sovereignty by putting a baby in her arms: but this "naturalism" is determined by a more or less well understood social interest." (Beauvoir 1980, 481).

"Ghosh's roots are in journalism and academic writinginvestigation and analysis, arevelation of subterranean connections and patterns- but first and foremost, and overriding all the many ideas that inform his work are the stories, the Dickensian proliferation of characters whose lives engage us and who take us to some richly imagined places and times" (John C. Hawley).His characters emerge out of history, and become a window for us to see and understand the society they belong to, the exploitation they are subjected to, and the factors that define who they are. In his Ibis trilogy he not only presents women characters from different social or racial background but also points out issues of their sexuality.

Sexuality has been an important theme in many of Ghosh's novels; and the most interesting aspect one can find in his novels is, undoubtedly, a reflection of how various cultures view sexuality. Amitav Ghosh's main female character Deeti, in Sea Of Poppies, is an example of how societal forces have deprived most women of their natural capacity to enjoy intimate gratifications. She was tricked into marrying Hukam Sing, an impotent man, by her own brother. On her first night she realized, "It was useless, she knew, to be seized by regret now, on the very night when her fate had been wedded to his: it was as if the shade of Saturn had passed over her face, to remind her of her destiny. Quietly, so as not to rouse him from his trance, she reached under her veil to wipe her eyes" (SOP 34). It did not take her long to come to the conclusion that, "he could never be a husband to her, in the full sense, either because his injury had rendered him incapable, or because opium had removed the inclination" (SOP 36).

In the phallocentric society of the early nineteenth century, Deeti had no way out of this sexless marriage, and had to remain his wife as long as he lived. Ghosh very tactfully presented before us how women's sexuality could be regulated, exchanged, and otherwise used for male benefit. Deeti was married to Hukam Sing solely for the sake of producing children. As her mother-in-law clearly stated, "One day, while massaging Deeti's belly, she said: And after we've delivered this one, we must make sure there are more- many, many more" (SOP 37). But as Hukam Singh was impotent, Deeti was drugged and raped by her brotherin-law on her first night, with the help of other in-laws as is revealed in the course of the novel. She was objectified, and the intention of her in-laws was to use her as a child- 
producing machine. The role that religion plays in suppressing female sexuality found an important place in Ghosh's Ibis trilogy. As we know, religions are mostly male dominated; and Christian religion like other religions on earth served as a restraining influence on female sexuality. Christian doctrines and sermons encourage sexual restraint and virtue. Mrs. Burnham's speech clearly indicates this view 'I must ask you to remember, Mr. Reid that ours is a Christian house and we do expect a certain modesty, in all things...' (FOF 38). Some normal human sexual activities are seen as 'disease' in Christianity, and these teachings are internalized by women like Mrs. Burnham, who then teaches it to others, as she writes in her letter to Mr. Reid, 'Afterwarsd Dr Allgood was kind enough to lend me another book: Mr Sylvester Graham's Lecture to Young Men on Chastity. You will find it enclosed herewith...Dr Allgood assures me that if any remedy for your Condition could be said to exist then this book is it' (FOF 119). And this so serious 'Condition' of $\mathrm{Mr}$ Reid is only a very normal self-satisfying sexual behaviour. Thus, Christianity has an important role to play in restricting sexuality.

But not only Christianity, Ghosh has shown other religions too playing the same role of restricting female sexuality, even to a greater extent. Taramony, the wife of Baboo Nob Kissin's uncle, was a young widow 'for her late husband had married her only for six years before, in a final effort to beget an heir' (SOP 161). Baboo Nob Kissin felt 'That his aunt wasm a woman of uncommon charm and comeliness' and 'now, rattling and rolling towardsBrindavan, in a succession of boats and carriages, the boy's defence crumbled.' It was very normal for them to get attracted towards each other. But their religion taught them to restrain their sexual behaviour. As Taramony explained to him, 'You will be my Krishna and I will be your Radha.... And you will live with me without touching me, without knowing my body' (SOP 162).Ghosh gave us example of another woman, belonging to another religion, totally different from the above mentioned two religions. She is Shireen Modi, who felt guilt about her second marriage. Through her Ghosh has shown that religious women feel guiltier than other women about many sexual activities, and that they act in ways suggesting sexual repression. Shireen Modi confesses to Freddie, 'And I will probably never again be able to enter a Fire Temple: that will be the hardest part' (FOF 523). Thus, religious faith has always provided a source of guilt to women about their own sexuality.

Lesbian activity is an important form of female sexuality. Ghosh in Flood of Fire shows examples of lesbian encounters. Mrs. Burnham has lesbian yearnings for Paulette, but she can reveal them only in secrecy, as such behaviours are severely condemned by society. She revealed her intentions to Zachary, 'I held you responsible for confounding my plans forPaulette. If not for you, I thought, she would have taken my advice and married MrKendalbushe, after which she and I would have been able to share many a happy goozle. I blame you for dashing my hopes' (FOF 224). Ghosh in River of Smoke has also shown that not only women but men also suffer because of society's intolerance to homosexuality.Robin is one such character who can hardly express his sexual orientation while he was in his homeland, but Canto provides him with better opportunities; there he finds 'a friend' Mr King. Thus, Ghosh tried to project the idea that in places where multiple cultures meet and society's restrictions become loose people are freer to express their different sexual orientations. And it is true for both the sexes.

\section{CONCLUSION}

Thus, Ghosh's exploration of double standard of sexual morality in his novels becomes very much apparent to us. He showed us the way and the necessity to deconstruct the cultural construct of sexual morality. It contrives to restrain certain sexual behaviours for women while favouring the exactly same behaviours for men. Through a thorough investigation of his The River of Smoke, Sea of Poppies and Flood of Fire, we are able to understand how the political ambition of men have often been lied on preventive women from experiencing satisfying sexual gratification. In an environment, where multiple cultures meet, women feel freer to express their true selves. The above research helped us to comprehend the whole process.

\section{NOTES}

1. For more see Encyclopaedia of Religion and Ethics. 6 vols. 567.

2. For more see- Downing, Christine (1994). "Lesbian Mythology". Historical Reflections. 20 (2): 176.

\section{REFERENCES}

[1] Beauvoir, Simone de. The Second Sex. Trans. Constance Borde and Sheila Malovan Chevallier. New York: Vintage Books, 1989.

[2] Buss, David M. The Evolution of Desire: Strategies of Human Mating. New York: Basic Books, 1994.

[3] Ditmore, Melissa H. Encyclopedia of Prostitution and Sex Work. Westport, Conn: Greenwood Press, 2006.

[4] Ghosh, Amitav. Sea of Poppies. New Delhi: Viking Press, 2008.

[5] ---. River of Smoke. New Delhi: Penguine India, 2011. 
[6] ---. Flood of Fire. New Delhi: Penguine India, 2015.

[7] Hawley, John C.Amitav Ghosh: An Introduction. New Delhi: Foundation Books Pvt Ltd, 2005.

[8] Hyde, J. S., \& De Lamater, J. Understanding human sexuality. 6th ed. Boston: McGraw-Hill. 1997.

[9] Huda, Ms Sigma. Report of the Special Rapporteur on the human rights aspects of the victims of trafficking in persons, especially women and children. UN Commission on Human Rights, 20Feb. 2006. Web. 26 June 2017. <http://www.refworld.org/docid/48abd53dd.html >.

[10] Montaigne, Michel. The Complete Essays of Montaigne. Trans. Donald M. Frame. Calif: Stanford University Press, 1965.

[11] Manu. The Laws of Manu. Trans. Wendy Doniger, Londen: Penguin, 1991, 147-148.

[12] P. S., \& Phillips-Yonas, S. "Women's liberation and human sexual relations". International Journal of Women's Studies 1. (1978): 83-95.

[13] Scruton, Roger. Sexual Desire. New York: The Free Press. 1986.

[14] Sherfey, M. J. "The Evolution and Nature of Female Sexuality in Relation to Psychoanalytic Theory". Journal of the American Psychoanalytic Association 14.1(1966): 28128.

[15] Wollstonecraft, Mary. Vindication of the Rights of Woman. London: J. Johnson. 1792. 